\title{
Task-based Learning and Language Proficiency in a Business University'
}

\section{Aprendizaje Basado en Tareas y Suficiencia de Inglés en una Universidad de Negocios}

\author{
Amelia Chloe Caroline Newsom-Ray and Sarah Jane Rutter²* \\ Universidad EAN, Colombia
}

\begin{abstract}
This project adds to the growing body of empirical research focusing on the effects of task-based learning (TBL) on second language acquisition. Through the design and implementation of two business English case studies, in which learning was scaffolded through a sequence of tasks, the authors argue that a TBL approach to language teaching more effectively engages students and promotes greater oral language proficiency than traditional approaches. The authors argue that guiding students to utilise and combine their existing knowledge and skills with vocabulary and structures presented in class to solve case study problems has the potential to result in greater student confidence and, subsequently, greater language proficiency. Nevertheless, various factors can significantly reduce the successfulness of TBL in this context, including disparate learner profiles in cultural and business knowledge, life experiences, motivation, as well as constraints in terms of time and institutional assessment.
\end{abstract}

Key words: Task-Based Learning (TBL), Business English, Case Studies, ESL, TESOL, Task Sequencing

\section{Resumen}

Este proyecto se suma a un significativo número de investigaciones empíricas, centrándose en los efectos del aprendizaje basado en tareas (TBL) en el proceso de adquisición de una segunda lengua. Mediante el diseño e implementación de dos estudios de caso en las clases de inglés de negocios, en las que el aprendizaje

1 Received: April 5, 2016 / Accepted: September 15, 2016

2 amelia.c.c.ray@gmail.com / sjrutter@universidadean.edu.co 
fue escalonado a través de una secuencia de tareas. Las autoras sostienen que el enfoque de aprendizaje basado en tareas involucra de manera efectiva a los estudiantes en el aprendizaje del idioma y promueve una mayor competencia del lenguaje oral que los enfoques tradicionales. Las autoras afirman que el guiar a los estudiantes en el uso y combinación de sus habilidades y conocimiento existente con el vocabulario y las estructuras presentadas en clase para resolver problemas de estudio de caso contribuyen a que el estudiante tenga mayor confianza y posteriormente un mayor dominio del idioma. Sin embargo, diferentes factores pueden reducir significativamente el éxito del aprendizaje basado en tareas en este contexto, incluyendo los diversos perfiles de los estudiantes en relación al conocimiento cultural y empresarial, experiencias, motivaciones, así como las limitaciones en términos de tiempo y evaluación institucional.

Palabras clave: Aprendizaje basado en tareas, inglés de negocios, estudios de caso, inglés como lengua segunda, Enseñanza de Inglés como Lengua Segunda, secuencia de tareas

\section{Resumo}

Este projeto se soma a um significativo número de pesquisas empíricas, centrando-se nos efeitos da aprendizagem baseada em tarefas escolares (TBL) no processo de aquisição de uma segunda língua. Mediante o desenho e implementação de dois estudos de caso nas aulas de inglês de negócios, nas que a aprendizagem foi escalonada através de uma sequência de tarefas escolares. As autoras sustentam que o enfoque de aprendizagem baseado em tarefas escolares envolve de maneira efetiva os estudantes na aprendizagem do idioma e promove uma maior competência da linguagem oral que os enfoques tradicionais. As autoras afirmam que o guiar os estudantes no uso e combinação de suas habilidades e conhecimento existente com o vocabulário e as estruturas apresentadas em aula para resolver problemas de estudo de caso contribuem a que o estudante tenha maior confiança e posteriormente um maior domínio do idioma. Entretanto, diferentes fatores podem reduzir significativamente o êxito da aprendizagem baseada em tarefas escolares neste contexto, incluindo os diversos perfis dos estudantes em relação ao conhecimento cultural e empresarial, experiências, motivações, bem como as limitações em termos de tempo e avaliação institucional.

Palavras chave: Aprendizagem baseada em tarefas escolares, inglês de negócios, estudos de caso, inglês como língua segunda, Ensino de Inglês como Segunda Língua, sequência de tarefas escolares 


\section{Introduction}

$\mathrm{T}$ This research project was developed in order to address an increasingly important area of second language acquisition: students learning English in order to compete in the international job market. The authors were interested in approaches which facilitate the effective development of communicative skills for business purposes. Moreover, the authors were particularly interested in the ways in which existing knowledge and skills can be harnessed and integrated in order to facilitate business-focused communication. To this end, a Task Based Learning (TBL) approach to Business English was applied in a South American university setting in order to investigate how redesigning modules of study into sequences of activities might facilitate students' oral communication skills.

Currently the Colombian government is implementing initiatives in order to increase bilingualism in the country. For example the National Bilingualism Programme, created by the Colombian Ministry of Education in 2004, offers all students the possibility to become bilingual in English and Spanish (De Mejía, 2011). As mastery of the English language is positioned as a fundamental aspect to this process, it is important to investigate best practice firmly situated within the Colombian context. This includes an analysis of current practices and initiatives in many contexts, including business settings.

At the university in this study, the application of case studies has proven challenging for students across all Business English courses at the university. Breen (1984) argues that by placing communication at the centre of the curriculum, both goal and means merge to become one and the same. Yet, we often witness students who are able to produce language in class activities, but who are less capable of producing spontaneous, unstructured dialogue. Consequently, TBL's emphasis on learning to communicate through interaction in the target language (Nunan, 2004) is of particular interest for the university. The ensuing research therefore aimed to explore the usefulness of TBL for increasing language proficiency including motivation, engagement and greater confidence with the language (Willis \& Willis, 2007).

In order to address these interests, the following two key research questions were created: How does TBL promote students' oral language proficiency in Business English? and How does TBL engage students in both content and oral language learning through the solution of business case studies? Results demonstrated that by employing Nunan's (2004) TBL approach to the development of Business English case study materials, TBL has the potential to lead to improved oral 
proficiency through greater student engagement, spontaneity, and communicative confidence through the provision of opportunities for the application of existing skills and socio-cultural knowledge in a way which supplements, complements, and encourages the integration of existing language skills and life experiences.

In sum, the authors found that by implementing a TBL approach to the use of case studies, students were indeed more engaged and increased their oral language proficiency. That said, various factors affected the successfulness of TBL including disparate learner profiles, life experiences, intrinsic motivation and time and institutional constraints. These factors thus highlight important areas for consideration for those implementing a TBL approach to syllabus design.

\section{Literature Review}

\section{Conceptualizing Task-Based Learning}

Task based learning (TBL) has its roots in communicative language teaching (CLT) (Nunan, 2004) which emphasises social interaction as fundamental for language acquisition (Myles \& Mitchell, 2004) and provides a practical means of applying the conceptually broad CLT (Skehan, Xiaoyue, Qian \& Wang, 2012). In practice, TBL involves using interactive tasks designed to be performed through real communication, as opposed to the teaching of a sequence of language items (Rozati, 2014), or specific linguistic forms (Rodríguez-Bonces, M. \& Rodríguez-Bonces, J. 2010). In this way, the learner is placed at the centre of the process (Nunan, 2004) and the teacher acts as a language consultant (Almagro Esteban \& Pérez Cañado, 2004), creating opportunities for meaningful language production and interaction (Willis \& Willis, 2007). Consequently, TBL focuses less on knowledge of a language and more on what learners can do with the language (Richards \& Rodgers, 2001).

\section{Task Based Learning Literature}

Tasks have been discussed and defined in many ways by researchers and educators, from focusing on the importance of communicative information exchange activities (Tang, Chiou \& Jarsaillon, 2015) to the form, complexity and scale of tasks (Thomas \& Wright, 1999), and the way in which language learners are forced into a variety of roles (Thomas \& Wright, 1999). Empirically speaking, as Robinson (2011) highlights, although TBL was initially conceptualised as a means for improving pedagogy, it only had a minimal foundation 
in empirical research regarding second language acquisition. TBL has since been studied in a number of different contexts, both qualitatively and quantitatively. For example, Carless (2002) investigated problems implementing task-based learning for young learners in a school setting. Murphy (2003) reflects on the relationship between tasks, teachers and learners. Yule, Powers and Macdonald (1992) undertook research with advanced proficiency learners, highlighting the way in which information transfer tasks may be enhanced when speakers are led to consider listeners needs, as opposed to the form of the speakers message. Rohani (2013) explored how task-based learning influenced the use of positive oral communication strategies and reduced the use of negative strategies. Interestingly, Tang, Chiou and Jarsallion (2015) researched how TBL developed verbal competence and found that TBL improved fluency, lexical, and syntactic complexity but did not improve accuracy. González Lopez and Cabrera Albert (2011), in a similar context to our own, looked at task-based learning principles in a Cuban university setting and highlighted fundamental principles of TBL which should be followed to implement TBL effectively.

Nevertheless, despite the growing body of literature, a gap currently exists with regard to empirical TBL research and language performance tasks in actual classroom settings (Calvert \& Sheen, 2015) and also regarding testing and syllabi design (Robinson, 2001). Moreover, the authors highlight an additional gap in the empirical literature in the use of TBL in tandem with a case study approach to (Business) English syllabi design and evaluation. The authors argue that TBL may prove beneficial in this particular learning context. Before discussing how TBL and the case method can work effectively together, it is worth briefly defining the case method.

\section{Task Based Learning and the Case Study Approach}

Case studies have been successfully used in many different educational fields, such as business, law and medicine, and it has been argued that case studies can also be useful in the context of English for Specific Purposes for Business (ESP-B) (Almagro Esteban \& Pérez Cañado, 2004; Beckisheva, Gasparyan, \& Kovalenko, 2015). Indeed, according to Boyd (1991), case studies are the most appropriate pedagogical model for ESP-B. As with TBL, a case study methodology requires students to interact and reflect by analysing and negotiating to solve a problem through which they are encouraged to freely and spontaneously use language in a meaningful context (Almagro, Esteban \& Pérez Cañado, 2004; Beckisheva, et al., 2015). Through the use of 
case studies, students discuss real life situations using concepts learned in the classroom whilst vocabulary and grammar are taught incidentally through content (Grosse, 1988; Nunan, 2004; Rodríguez-Bonces, M. \& Rodríguez-Bonces, J. 2010). Moreover, TBL and the case method further align in that TBL promotes the linking of classroom learning with language used outside the classroom through 'real-world' tasks (Nunan, 2004; Rozati 2014).

Almagro, Esteban and Pérez (2004, p.158) gathered data about the efficacy of the case method and put forward several factors which contributed to students' success, including a) a warm-up phase, b) clear presentation of the scenario, c) anticipation of students' linguistic needs, and d) teamwork to encourage learning, all factors which align well with Nunan's (2004) TBL sequencing. Finally, throughout the unit of work, students are active learners working together to construct their knowledge. Nevertheless, case studies can be difficult for both students and teachers due to the integrated multiple skills needed to perform proficiently (Almagro Esteban and Pérez Cañado, 2004). By following Nunan's (2004) sequencing, as outlined in the methodology section, the authors posit that TBL can overcome some of these difficulties through mini tasks to promote the communicative skills required to participate effectively in case studies.

\section{Methodology}

\section{Research Design}

Maintaining that teachers are fundamental in education research within the education field, the researchers employed action-research (Stenhouse, 1993: Elliot, 1994) to investigate the applicability of task-based learning (TBL) to address a problem encountered at the university; students exhibiting difficulties producing spontaneous dialogue, particularly in case study-based classroom activities and assessment tasks. More specifically, the authors found that whilst students were able to produce explicitly taught language correctly in controlled grammar practice or vocabulary activities, they appeared much less able to integrate various elements of language learning in order to communicate spontaneously in freer, less controlled activities. Consequently, the researchers, concerned with bridging this gap, redesigned aspects of the syllabus for an Intermediate Business English class in line with Nunan's (2004) TBL approach. The researchers then implemented this redesign and examined the usefulness of employing such an approach as a means to improve communicative competencies and encourage greater student engagement and participation. 


\section{Context}

The university, located in the capital of Colombia, has a business focus with the objective of preparing students to work in a multinational business setting. The university is medium sized with most students coming from middle class backgrounds. Through the Modern Languages programme, students aim to develop a B1 level for three different languages, according to the Common European Framework (Council of Europe, 2001), with the objective of acquiring the skills necessary for a competitive international business environment. Modern Language students progress through four levels of English including Basic Business English I, Basic Business English II, Intermediate Business English and Upper Intermediate Business English before continuing their English studies with content classes, that is to say, classes which are content based but taught through the medium of English. Content courses include International Business, Business Speech, English Culture and International Culture. Business English courses at the university often use case studies as a teaching method and speaking evaluation tool. The textbook currently used by the university is Market Leader (Cotton, Falvey \& Kent, 2010).

\section{Intervention}

The sequences of classes used in the study were adapted from the aforementioned textbook. It is important to note that each unit of the textbook involves a case study in which students are expected to find a solution to a problem or complete a complex communicative task. These case studies at the university constitute speaking assessment tasks. However, the case studies in the textbook and the activities leading to their solution are mismatched in that they do not suitably prepare students for the final task. For this reason, the professor adapted two units from the textbook and employed Nunan's (2004) TBL sequencing with the objective of better preparing students for the assessment tasks.

According to Nunan (2004), TBL should meet the following principles: 1) the tasks need to be scaffolded; 2) one task should lead to another task; 3) materials should be recycled; 4) learners construct their knowledge actively; 5) tasks integrate linguistic form, communicative function and semantic meaning; (6) tasks allow learners to move from repetition to creative, freer activities; and (7) students have time to reflect on their learning. With these criteria in mind, the units of work were adapted to include vocabulary, grammar, reading and listening tasks and skills language (set expressions from the textbook) to prepare for the case studies. These were then taught as a series of mini tasks 
leading following Nunan's (2004) six steps for TBL, as demonstrated in Figure 1 below.

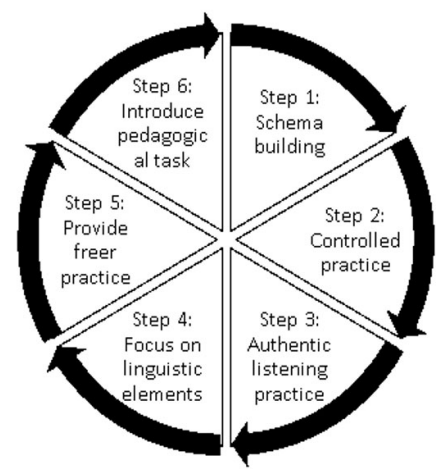

Figure 1. Task based learning sequencing (Authors' representation)

Sequence one. The first sequence of classes involved a series of mini tasks aimed at developing students' abilities to participate in a business meeting in which sponsorship options were discussed. In the first stage, schema-building, students were introduced to brands and marketing vocabulary and participated in activities such as gap fills, crosswords and writing tasks. Students also participated in a brainstorming activity in which they discussed desired qualities of a potential sponsor. The following stage involved listening to a meeting at a sponsorship agency in which sponsorship options for a media company were discussed. This conversation was very similar to what students would be expected to produce later during the case study. After completing the listening activity, students practiced the dialogue and adjusted it to be more relevant to the Colombian context. The sequence of classes included a linguistic focus on expressions students could use for the meeting, including expressions to ask for/give opinions, agree, disagree and make suggestions. After four classes of context setting and controlled practice, students were asked to write a business style letter in which they outlined a suitable sponsorship candidate for their 100 company with supporting reasons as to why this candidate should be selected. The writing task utilised the vocabulary and expressions presented in the previous classes and modelled the language they could use in the pedagogical task.

After schema building, controlled practice, listening practice, focus on linguistic elements, and writing practice; students participated in the pedagogical task. This involved students role-playing a meeting 
in which they discussed different options and selected a sponsor for a sportswear company.

Sequence two. In the second sequence of classes, students prepared a presentation about how to conduct business in a culture different from their own. Students needed to include advice and suggestions about cross-cultural negotiations in an appropriately structured presentation. Throughout the sequence, there were class discussions about different cultures and students were asked to draw comparisons between their own culture and those of others. Students participated in reading and listening activities about cultures in general, as well as cross-cultural business interactions in which problems may arise. Students studied modal verbs of advice, obligation and necessity which wold aid students in giving advice and explaining cross-cultural rules/norms. This linguistic focus was taught within the context of cross-culturally negotiations with the language embedded in reading and writing tasks. Presentation structure and expression to use in a presentation were taught and practiced in class. The sequence of classes lead to the final pedagogical task which was an assessed presentation about a doing business cross-culturally in any chosen country.

\section{Participants}

The students. Nine students enrolled in the course: five female Modern Language students, Karol, Bibiana, Daniela, Sandra and Andrea (pseudonyms) who, on average, were seventeen years old. Four had completed the previous level of English at the university the previous semester, the other student, Daniela, had previously failed Intermediate Business English and was repeating the course. The other four students were teachers at the university: Gabriela, Mariana, Ana and Mateo (pseudonyms). The youngest was approximately thirty years old and the oldest in his sixties. All of them had plentiful teaching experience; two of them, Gabriela and Mariana, were second language teachers of German and French. Mateo was a marketing teacher. Ana worked in a teaching capacity at the university. She had studied the previous level of English the previous semester. Due to time constraints and work demands, Ana dropped out of the course mid-semester.

It is important to note an inconsistency of student attendance as well as a large discrepancy in terms of metalinguistic and cultural knowledge, language level, and life experience between the modern language students and teachers. All the teachers had travelled abroad, Mateo extensively. Gabriela and Mariana, as language teachers, had greater metalinguistic knowledge than the students in the class. 
The teacher. The teacher was a native English speaker with a Master's degree in teaching and six years ESL teaching experience.

Class frequency. During the first half of the semester, classes met for two hour classes twice a week over a two month period. During the second half, classes increased to three times a week, again over a two month period. Each unit of work, structured using TBL methodology, consisted of seven classes.

\section{Data Collection Instruments}

Four instruments of data collection were used: the professor's personal reflections, class observations, evaluation scores and attendance rates.

Professor's personal reflections. The professor provided written reflections regarding the TBL process, students' progress, and course units.

Class observations. During the second case study, the classes were observed by two other professors in order to record their opinions about classroom interactions, student engagement, and language proficiency.

Evaluation scores. Students received a grade based on their level of performance in the case study at the end of each sequence of classes. In the first sequence of classes, oral performance during the role play was analysed and measured against the criteria taken and adapted from the Cambridge Business English Certificate Handbook (2012). This was chosen due to its usefulness for assessing ability to hold a conversation without over-emphasising form. According to this, students were rated as excellent, very good, good, fair, poor, or not shown in reference to these criteria: a) ability to sustain a dialogue (discourse management); b) linguistic capabilities, such as being able to structure a sentence correctly (language); c) ability to produce intelligible output with good sentence stress (pronunciation); d) ability to maintain and develop interactions and respond appropriately during conversation (interactive communication) and; e) their ability to use appropriate vocabulary to make suggestions, agree and disagree (vocabulary). A percentage score was then generated which counted towards their semester grade.

For the second sequence of classes, students' oral performance was measured against criteria adapted from the Market Leader peer assessment rubric (2010, p. 109) for assessing the effectiveness of a presentation. In addition to this, the teacher added the following 
criteria: grammar, use of target vocabulary, and pronunciation. Similar to the first sequence of classes, students were rated as excellent, very good, good, fair, poor, or not shown, and a percentage score was then generated which counted towards their semester grade.

Attendance rates. The teacher kept a role of students attending the class and noted down, not only if students were absent, but also if they were late to class.

\section{Data Analysis and Interpretation}

Two researchers participated in the analysis of the data. Both researchers read the data individually and then exchanged perspectives in order to analyse the way in which TBL engaged students and promoted oral proficiency. In order to do so, both qualitative and quantitative means were employed. In terms of quantitative data, attendance and final evaluation scores were collated. With regard to qualitative measures, the ways in which students interacted with the teacher, the materials and the other students were considered i.e. the extent to which they asked and responded to questions, appeared engaged or disengaged, integrated knowledge from outside the classroom context, and their oral performance during classes and in evaluations.

For case study one, student evaluations were based on the ability to conduct a successful negotiation. A successful negotiation was defined as the ability to a) present their chosen candidate and give supporting reasons as to why their candidate should be chosen, and b) discuss the sponsorship possibilities, and as a group, choose the most appropriate candidate. With regard to the second case study, the focus was on developing students' ability to present information about a culture different from their own and to present suggestions and obligations about doing business cross-culturally.

\section{Results}

On the basis of data acquired, the researchers gleaned that TBL can be an effective tool but with limitations. Below, we will discuss students' grades for the pedagogical task, attendance levels, and prior knowledge and life experiences, and how these factors were related to the utility of TBL.

Assessment scores indicated how consistent engagement with each stage of the TBL sequencing promotes oral proficiency. For 
example, in the first case study, Bibiana, a Modern Language student, who started the course with a lower level than many of the other students, provided an excellent illustration. Despite her initial lower level, as the only student to attend all classes, she achieved a high final grade of $88 \%$ for the first case study. She was able to integrate and apply taught vocabulary and expressions and effectively utilise target structures. In contrast, Sandra, another Modern Language student, who missed two classes covering grammar, the writing workshop, and speaking practice, unsurprisingly, exhibited poor performance. Although the grammar and vocabulary produced were fair, she lacked the ability to listen and respond naturally, resulting in dialogue lacking in spontaneity. Similarly, Karol and Andrea, Modern Language students, who started the course late, whilst performing reasonably well, demonstrated a tendency to rely on others for the flow of conversation.

In the second case study, Bibiana and Sandra, who worked together, missed key phases of the TBL sequencing designed to prepare them for the final presentation. During the final assessment, Sandra incorrectly used modal verbs, did not use the structures or phrases taught during the classes, and failed to include any business information. Similarly, Bibiana's lack of preparation was also apparent through insufficient content, despite some attempt to use taught structures and modal verbs. In the case of these two students, the TBL process was not effective as, due to poor attendance, they were unable to undertake each of the mini-tasks successfully. Consequently, they obtained lower evaluation scores in comparison with other students. Moreover, neither were motivated to create an effective presentation, and the time constraints of the course did not allow them to develop sufficient oral proficiency. In contrast, Marianna and Gabriela, language teachers, benefited greatly from each stage as they took advantage of opportunities to participate and engage with materials and practice taught forms. Consequently, there were able to integrate and apply what had been studied to deliver a well-structured, highly engaging presentation.

Secondly, the importance of previous experience beyond the classroom and materials relevant to students' day-to-day lives was 104 crucial. For example, Ana, one of the education professionals, who also missed two classes in the first unit and started with a lower level than her peers, performed well in the first case study. Whilst demonstrating structural and pronunciation problems, she clearly listened to her peers and responded appropriately. In fact, overall, she demonstrated a strong ability for interactive communication and, at times, dominated the conversation. In comparison, although Sandra was able to utilise taught 
structures, she performed poorly as she was unable to communicate spontaneously. Likewise, Karol and Andrea memorised vocabulary and phrases, however, lacked overall fluency. The authors argue that Ana's previous experience of business negotiation was extremely helpful during this task. Indeed, she performed significantly better regardless of the use of specific taught structures and clarity of pronunciation.

Similarly, in the second case study, Mateo's presentation, a marketing teacher, was well structured and coherent, using presentation phrases introduced in class. Furthermore, he naturally integrated modal verbs and demonstrated a high level and breadth of vocabulary to convey extensive information. Notably, he was always the most vocal student in classes and demonstrated clear interest in the topic and significant background knowledge, which he was able to synthesis and elaborate. This existing knowledge strengthened the final product as he was able to focus on the application of taught structures and vocabulary and naturally respond to questions. Overall, he demonstrated a high level of oral proficiency motivated by a strong interest in the subject matter and complemented by extensive cross-cultural life experience.

Likewise, Marianna and Gabriela's presentation was wellstructured and linguistically sophisticated. Clearly, their existing cultural knowledge, from having lived and worked in different countries, also facilitated their contributions. These students were clearly engaged by the materials, and consequently, did exceptionally well. Furthermore, both had prior business knowledge and were education professionals. Whilst the class materials honed existing skills, particularly their ability to express opinions and make suggestions in a structured and accurate way, arguably, the tasks also had greater relevance for their working lives. Indeed, it was clear that their life and work experiences had an impact on their motivation and level of engagement, which in turn, had a significant influence on their ability to communicate. Evidently, the way in which TBL allowed these students' the space to express life experiences through taught structures was complimentary and thus extremely effective in terms of developing their oral proficiency.

In both case studies, the mixed group of students led to many pedagogical challenges. Students from the Modern Language programme had a much lower level of English than the teachers; even though they were undertaking a B1 level course, the Modern Language students had an average of an A2 level (Council of Europe, 2014). Moreover, the younger Modern Language students, who had never travelled, were not only much less able to pick up on new grammatical patterns quickly; they also often lacked sufficient cultural and professional knowledge for 
the successful completion of tasks. Indeed, as Calvert and Sheen (2015) have noted, students' lack of ability to perform tasks may stem from unfamiliarity with the concepts or tasks themselves. This highlights the importance of carefully tailoring TBL tasks according to the cultural and professional background of students.

\section{Conclusions}

Results of the analysis of the above intervention demonstrates that TBL is certainly applicable to the university's Business English programme. The design and implementation of Nunan's (2004) approach provides a clear and effective means of scaffolding learning through sequences of communicative tasks. More specifically, it has the potential to engage students by providing opportunities for them to apply existing skills and socio-cultural knowledge in the language learning environment. In this way, such a restructuring of materials can supplement and complement existing language skills and cultural and professional experiences whilst allowing students to express themselves with the support, but not constraint, of target language and structures.

As a consequence of its application, many of the students were more confident and able to spontaneously produce dialogue as evidenced by the effective use of language, vocabulary, and structures in the final business case study tasks. Whilst this indicates an overall improvement in oral language proficiency, two key areas for consideration were highlighted.

Firstly, one issue illuminated by the project was the necessity for recycling materials to develop proficiency. This was made difficult, however, due to the poor attendance of students. Despite reinforcing material studied in earlier classes to give repetitive exposure, it simply was not viable, and as a result, the units of work lacked continuity. In fact, a review of material often made no sense to students because they had not attended the class in which the topic was initially introduced.

Secondly, research suggests using real-life situations in the classroom makes materials more relevant to students' needs (Almagro 106 Esteban \& Pérez Cañado, 2004; Beckisheva, et al, 2015; Nunan, 2004; Rozati, 2014). Indeed, as was demonstrated, students' life experiences and the future applicability of content had an impact on the way in which they interacted with materials and impacted on motivation. However, problems can arise when the gap between students' language abilities and life experiences are too great, and materials are more relevant 
and applicable to the lives of some and not others. This highlights the importance of developing materials highly relevant and applicable to students' lives as well as age and culture in order to maximise success for all students. According to Platt and Brooks (2002) for second language acquisition to be at its best, task engagement must take place. Indeed, many students in the class did not seem strongly engaged, as evidenced by their low attendance and observations of classroom behaviour. The authors argue that low motivation and engagement on the part of the younger Modern Languages students may have been significantly related to the relevance and level of the materials. Indeed, many of the younger students had difficulty participating in business role-plays, arguably highlighting the way in which different ages and life experiences can create large discrepancies in oral proficiency simply as a consequence of the materials. Indeed, as Calvert and Sheen (2015) argue, although a task does not appear to be successful, this does not mean that it is an ineffective means of learning. Rather, the structure, input, and implementation according to the specific learner population may not have been appropriate.

In summary, the authors found that TBL has the potential to engage students and promote oral proficiency in the context of Business English case studies. However, the findings highlighted the importance of using highly relevant materials as a means to enhance student engagement and motivation, not only in terms of the future needs of students, but also in terms of existing life experiences. This is arguably particularly important in the context of Business English with young students. Additionally, an area which proves crucial for the development of learners' skills, and fundamental for improving oral proficiency, is the coherent and repetitive recycling of materials during task sequences. As follows, consistent attendance and institutional time and assessment constraints which impede sufficient repetition are fundamental considerations. One area for further consideration then is the question of how educators can effectively design TBL sequences which harness the varying levels and life experience in diverse groups in a way which is beneficial for the whole. 


\section{References}

Almagro Esteban, A., \& Pérez Cañado, M. (2004). Making the case method work in teaching business English: a case study. English for Specific Purposes, 23, 137-161.

Beckisheva, T. G., Gasparyan, G. A., \& Kovalenko, N. A. (2015). Case study as an active method of teaching business English. Procedia Social and Behavioral Sciences, 166, 292-295.

Boyd, F. A. (1991). Business English and the case method: A reassessment. TESOL Quarterly, 25(4), 729-734.

Breen, M. (1984). Processes in syllabus design. In C. Brumfit, General English syllabus design (pp. 47-60). Oxford: Pergamon Press.

Calvert, M., \& Sheen, Y. (2015). Task-based language learning and teaching: an action-research study. Language Teaching Research, 19(2), 226-244.

Carless, D. (2002). Implementing task-based learning with young learners. ELT Journal, 56(4), 389-396.

Cotton, D., Falvey, D., \& Kent, S. (2010). Intermediate market leader (3rd ed.). Essex: Pearson Education Limited.

Council of Europe. (2001). Common European framework of reference for languages: Learning, teaching assessment. Cambridge: Cambridge University Press.

de Mejía, A. M. (2011). The national bilingual programme in Colombia: imposition or opportunity? Apples - Journal of Applied Language Studies, 5(3), 7-17.

González López, I., \& Cabrera Albert, J. S. (2011). El aprendizaje del inglés con fines profesionales basado en el enfoque por tareas: una experiencia con estudiantes de ingeniería forestal. Pedagogía Universitaria, XVI(4), 85-107.

Grosse, C. U. (1988). The case study approach to teaching business English. English for Specific Purposes, 7(2), 131-136.

Murphy, J. (2002). Task-based learning: the interaction between tasks and learners. ELT Journal, 57(4), 352-360.

Myles, F., \& Mitchell, R. (2004). Second language learning theories (2nd ed.). New York, USA: Routledge.

Nunan, D. (2004). Task-based language teaching. Cambridge: Cambridge University Press. 
Platt, E., \& Brooks, F. B. (2002). Task engagement: a turning point in foreign language development. Language Learning, 52(2), 365-400.

Richards, J., \& Rogers, T. (2004). Approaches and methods in language teaching. Cambridge: Cambridge University Press.

Robinson, P. (2011). Task-based language learning: a review of issues. Language Learning, 1-36.

Rodríguez-Bonces, M., \& Rodríguez-Bonces, J. (2010). Task-based language learning: old approach, new style. A new lesson to learn. Profile, 12(2), 165-178.

Rohani, S. (2013). Positive versus negative communication strategies in task-based learning. TEFLIN Journal, 24(2), 158-179.

Rozati, S. M. (2014). Language teaching and task based approach. Theory and Practice in Language Studies, 4(6), 1273-1278.

Skehan, P., Xiaoyue, B., Qian, L., \& Wang, Z. (2012). The task is not enough: Processing approaches to task-based performance. Language Teaching Research, 16(2), 170-187.

Tang, H., Chiou, J.-S., \& Jarsaillon, O. (2015). Efficacy of task-based learning in a Chinese EFL classroom: a case study. English Language Teaching, 8(5), 168-178.

Thomas, H., \& Wright, T. (1999). The role of facilitator training and the development of process competence. In R. Budd, Redesigning the foreign language classroom. Paris: Triangle XV.

University of Cambridge. (2012). Cambridge English business certificates handbook for teachers. Cambridge: University of Cambridge.

Willis, D., \& Willis, J. (2007). Doing task based teaching. Oxford: Oxford University Press.

Yule, G., Powers, M., \& Macdonald, D. (1992). The variable effects of some task-based learning procedures on L2 communicative effectiveness. Language Learning, 42(2), 249-277. 


\section{Authors}

*Sarah Jane Rutter earned her Masters of Teaching with a focus on TESOL and LOTE from Deakin University, Australia in 2011. She also holds a BA from The University of Melbourne and certificate IV in Training and Assessment from Box Hill TAFE. She has worked in a variety of language teaching roles, including teaching positions at universities, language institutes, refugee centres, technical and further education (TAFE) and high schools. Sarah is currently teaching Business English at a university in Bogotá, Colombia.

*Amelia Chloe Caroline Newsom-Ray holds a Masters of Science in Psychosocial Studies and a BA (Honours) in Applied Psychology and Criminology from the University of Brighton. She is currently teaching ESL in the United Arab Emirates. 